\title{
TWO-CASE REPORTS OF PLASTIC SURGERY TREATMENT OF RHINOPHYMA
}

\author{
Rosen TSOLOV ${ }^{\boxplus}$, Georgi YORDANOV ${ }^{2}$, Nikolay PAVLOV ${ }^{3}$ \\ ${ }^{1}$ Clinic of Maxillo-Facial Surgery, University Hospital "St. George”, Medical University of Plovdiv, Plovdiv, \\ Bulgaria \\ ${ }^{2}$ Department of Radiology, Dental Allergology and Physiotherapy, Faculty of Dental Medicine, Medical \\ University of Plovdiv, Plovdiv, Bulgaria \\ ${ }^{3}$ Clinic of Maxillo-Facial Surgery, University Hospital "St. George”, Medical University of Plovdiv, Plovdiv, \\ Bulgaria
}

Received 06 Jan 2021, Accepted 24 Febr 2021

hitps://doi.org/10.31688/ABMU.2021.56.1.16

\section{Abstract}

Introduction. Rhinophyma is a disfiguring nasal deformity due to the proliferation of sebaceous glands and underlying connective tissue. It affects mainly men, aged between 50 and 70 years old. The disease is associated with negative stigma, low self-esteem, reduction in quality of life. The main reasons patients seek medical help are cosmetic problems and functional impairments. Surgery is indisputably the treatment of choice for rhinophyma.

Cases report. We present the cases of two patients diagnosed with rhinophyma, who underwent surgical treatment in the University Hospital "St. George", Plovdiv, Bulgaria. The subtlety and innovation of the surgery was that the hypertrophied skin of the nose was dissected in layers, the sebaceous glands that produced pus were extirpated. The normal glands sought to be preserved, to nourish the newly formed dermis postoperatively. Both patients responded well to the procedure, without postoperative complications or wound infections.

\section{Résumé}

Traitement chirurgical reconstructif du rhinophyma: rapport de deux cas

Introduction. Le rhinophyma est une déformation nasale défigurée due à la prolifération des glandes sébacées et du tissu conjonctif sous-jacent. Elle affecte principalement les hommes âgés de 50 à 70 ans. La maladie est associée à un stigmate négatif, une faible estime de soi et une réduction de la qualité de vie. Les principales raisons pour lesquelles les patients recourent à une aide médicale sont les problèmes esthétiques et les déficiences fonctionnelles. La chirurgie est incontestablement le traitement de choix du rhinophyma.

Rapports de cas. Nous présentons les cas de deux patients diagnostiqués avec la maladie rhinophyma, qui ont subi un traitement chirurgical à l'Hôpital Universitaire «St. George», Plovdiv, Bulgarie. La subtilité et l'innovation de la chirurgie étaient que la peau hypertrophiée du nez était disséquée en couches, les glandes sébacées qui produisaient du pus étaient extirpées. On a essayé de préserver les glandes normales 
Conclusions. These cases highlight the importance of an accurate treatment of rhinophyma and the post-operative period, and the need for an appropriate follow up of patients until the complete recovery of the surgical wound and the formation of new skin.

Keywords: rhinophyma, rosacea, surgical-plastic treatment.

\section{INTRODUCTION}

Rhinophyma is a disfiguring nasal deformity due to the proliferation of sebaceous glands and underlying connective tissue. The name itself is broken down into "rhis" derived from Greek, meaning nose, and "phyma" also Greek, for skin tumor ${ }^{1}$. Acne rosacea is the precursor condition to later development of rhinophyma. In 1846, Ferdinand von Hebra described rhinophyma as the ultimate expression of rosacea ${ }^{1-3}$. Historically, the condition has been known to exist, as seen in a $15^{\text {th }}$ century painting by Domenico Ghirlandaio, "An Old Man and His Grandson", which shows a man with a large rhinophyma ${ }^{1}$.

Rhinophyma belongs to the "late rosacea" stage in the classification made by Wilkin in 1994: pre-rosacea, vascular rosacea, inflammatory rosacea, and late rosacea $^{1}$. While acne rosacea is more common in females, rhinophyma is commonly found in white men over the age of 50 years, with a male to female ratio of 5 to 1 to afin de nourrir le derme nouvellement formé après l'opération. Les deux patients ont bien répondu au procédé, il n'y a eu aucune complication postopératoire or infection de plaie.

Conclusions. Ces cas mettent en évidence l'importance d'un traitement précis du rhinophyma, la nécessité d'un traitement approprié du patient, l'importance de la période postopératoire et du suivi de l'état des patients jusqu'à la guérison complète de la plaie chirurgicale et à la formation d'une nouvelle peau.

Mots-clés: rhinophyma, rosacée, traitement chirurgical-plastique.

30 to $1^{1,4}$. There is a hypothesis that androgenic influences predispose rhinophyma development in males ${ }^{1,4}$.

This disfiguring disorder is essential to treat, as patients are subjected to psychological distress and respiratory issues when alar thickening can obstruct the external nasal valves ${ }^{1}$. Because, in the past, rhinophyma was considered a clinical sign of heavy alcohol consumption, the disease is associated with negative stigma, low self-esteem, reduction in the quality of life and colloquial terms for the rhynophyma include "whiskey nose", "gin blossom", and "potato nose",,2,5. Surgery is indisputably the treatment of choice for rhinophyma, because it responds poorly to the medical treatment ${ }^{6,7}$.

\section{Cases presentation}

We present two patients aged 52 and 56 years old, respectively, with hypertrophic growth of the skin of the nose, resembling a trunk, also known as rhinophyma (Fig. 1,2). The patients, who neglected
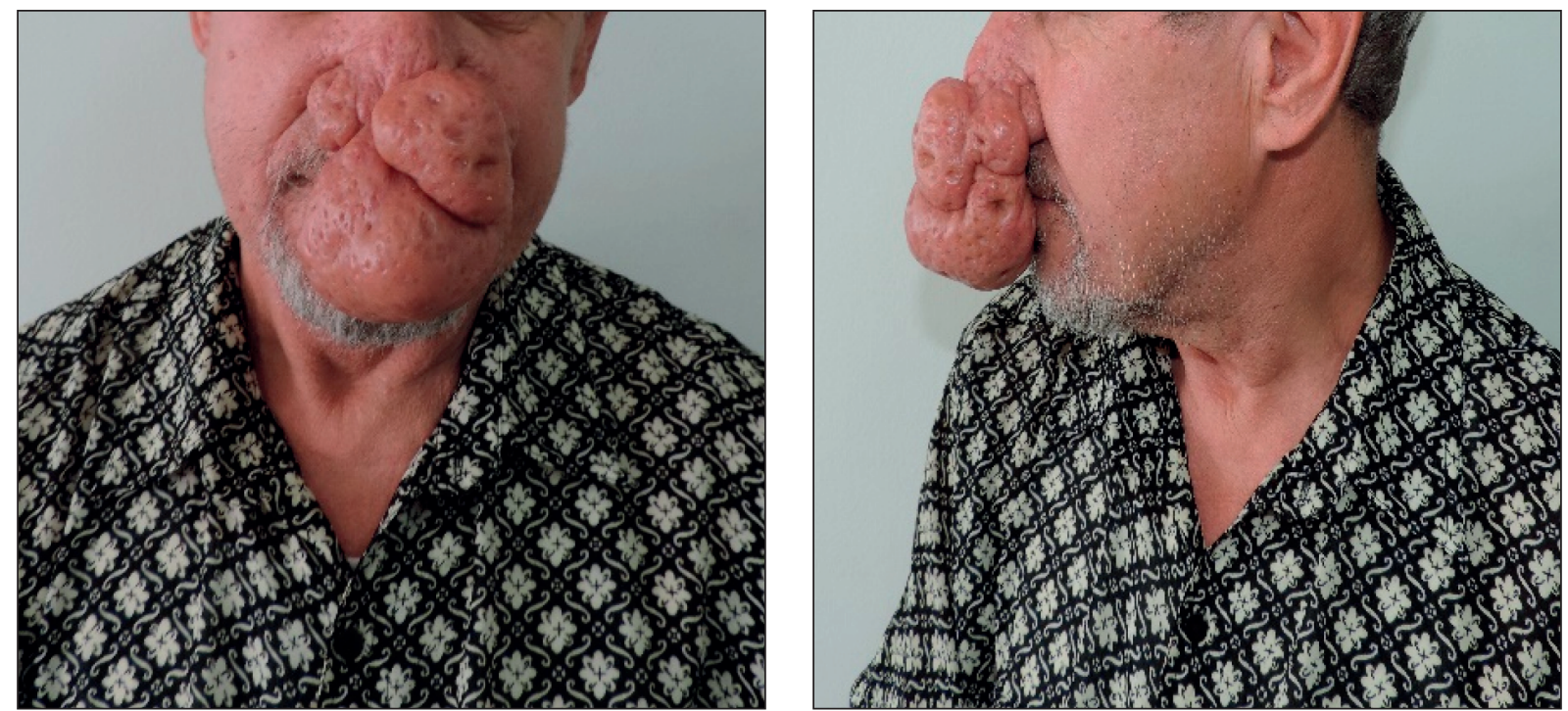

Fig. 1. Patient 1. Preoperative view 

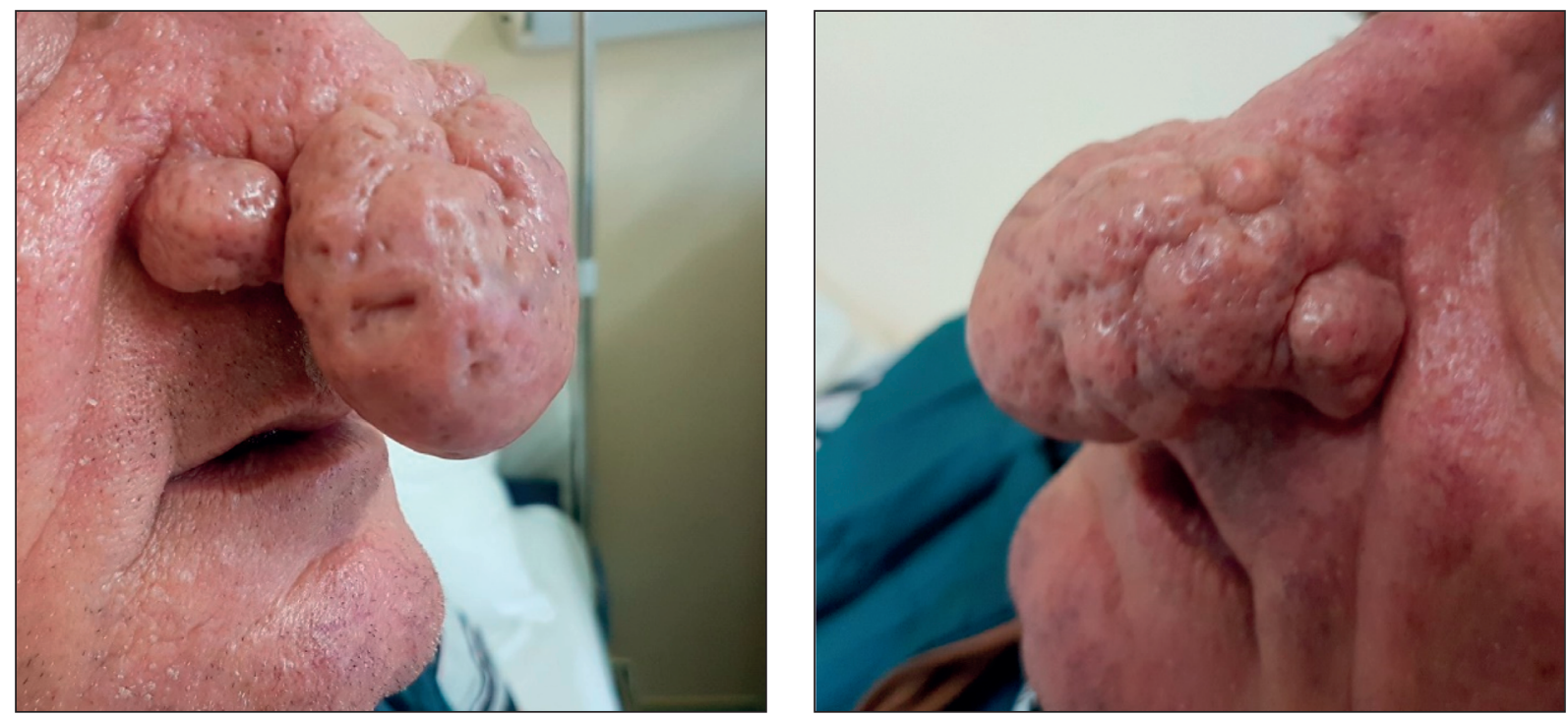

Fig. 2. Patient 2. Preoperative view
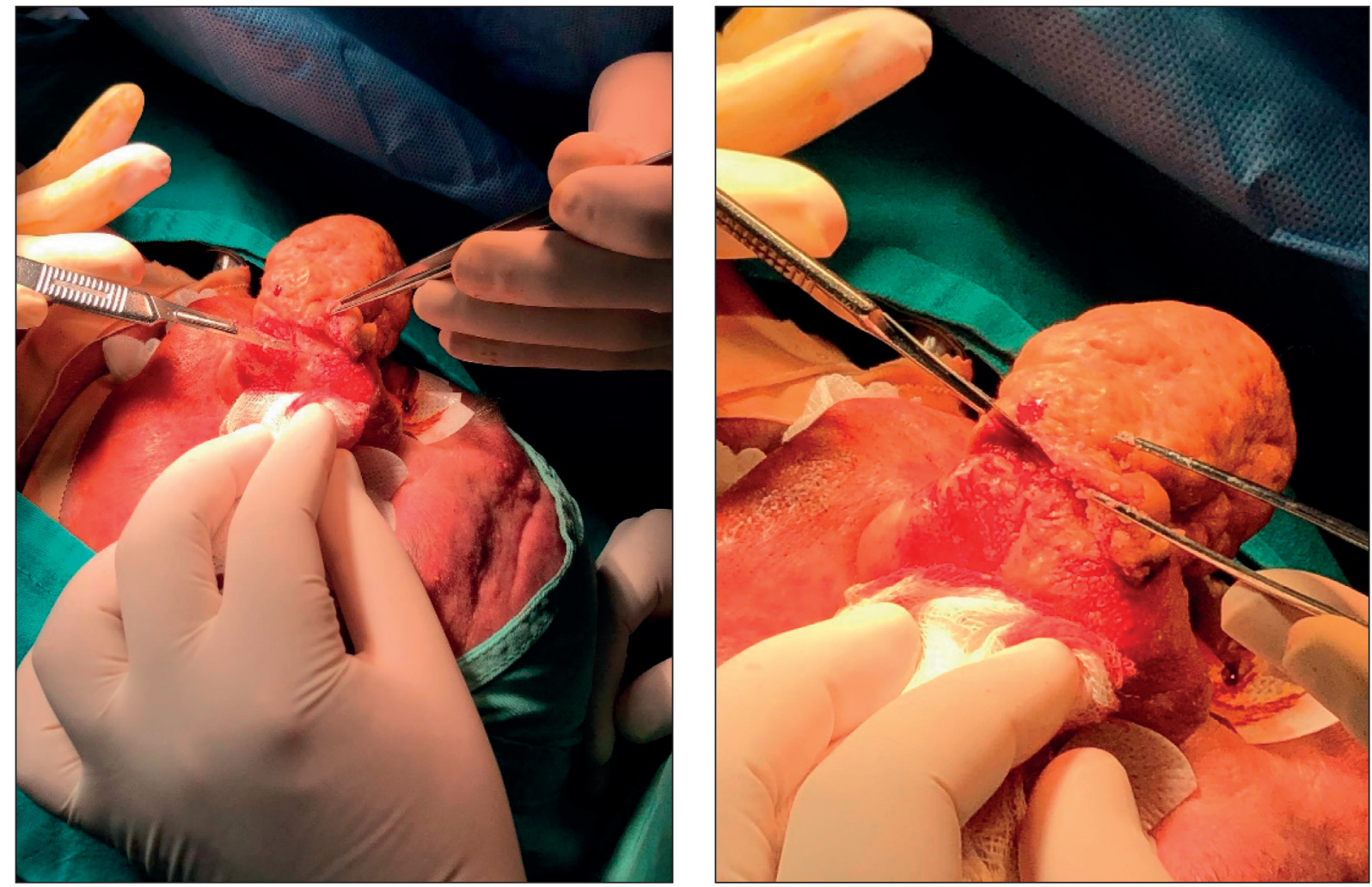

Fig. 3. Intra-operatory images.

the disease, were referred for surgical treatment to the Clinic of Maxillo-facial Surgery, University Hospital "St. George", Medical University of Plovdiv, Bulgaria.

According to the peculiar characteristics of each patient, both men underwent surgery under general anesthesia (Fig. 3). The subtlety and innovation of the surgery was that the hypertrophied skin of the nose was dissected in layers and the sebaceous glands that produced pus were extirpated. The normal glands sought to be preserved, to nourish the newly formed dermis postoperatively.

Another main surgical objective was to preserve the contour and boundaries of the normal nose, which are violated by the rhinophyma (Fig. 4). It was also mandatory to form a normal nasal cartilage in case it was disturbed by rhinophyma.

Both patients responded well to the procedure, without any postoperative complications or wound 
infections. The healing period and the care of the operative wound are extremely important. In the cases exposed, the patients' condition was followed up 14 days after surgery (Fig. 5,6), the $30^{\text {th }}$ day (Fig. 7,8), and in the $3^{\text {rd }}$ month (Fig. 9,10), until the complete recovery of the surgical wound and the formation of new skin. The patients reported improved breathing and contentment with their appearance.

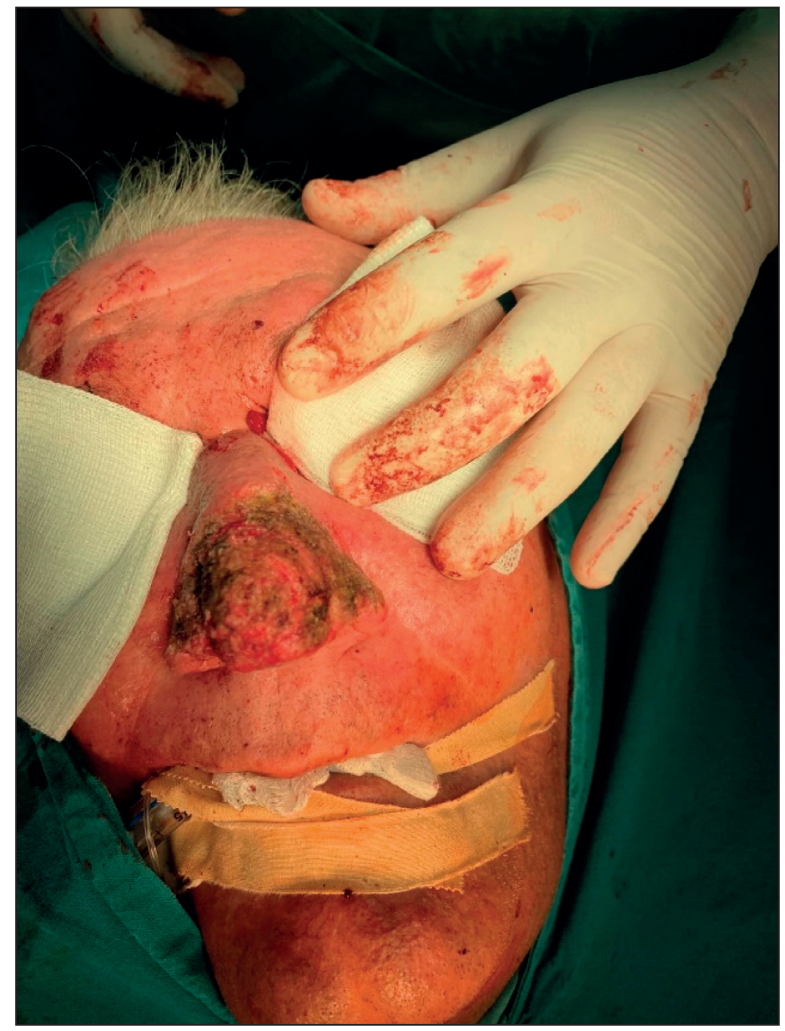

Fig. 4. Patient 2 after surgery

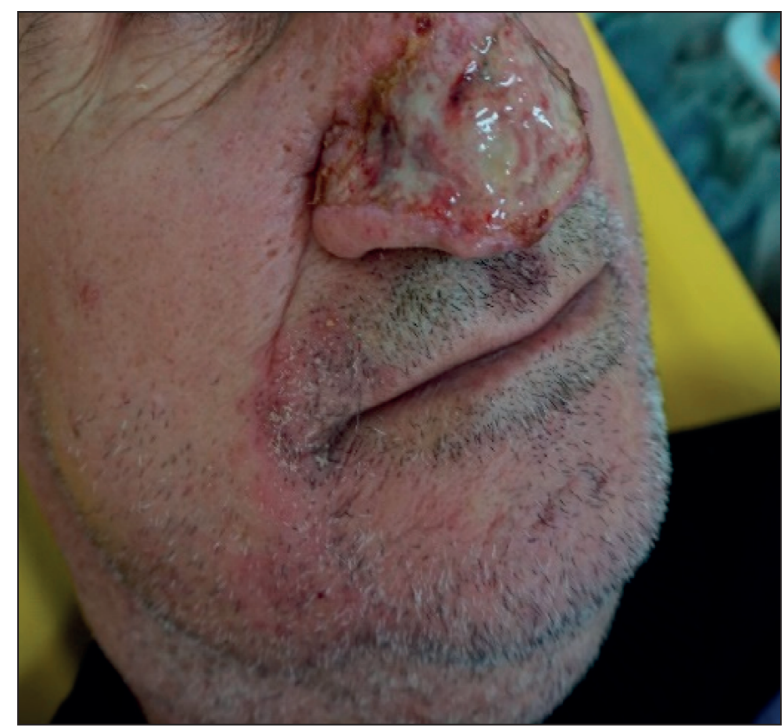

Fig. 5. Patient 1 on the $14^{\text {th }}$ day after surgery
Both patients were treated successfully and have satisfying functional and aesthetic results. In both cases, the surgical wound healed and the cosmetic and long-term results were excellent. The post-operative results were symmetrical and the patients are satisfied with the outcome of the treatment.

\section{Discussion}

There are different hypotheses regarding the etiology of rhinophyma, taking into consideration the role of environmental factors, genetic factors and different microorganisms. Usually, patients seek professional help because of cosmetic and functional reasons, but, in the advanced cases, the main problems are nasal respiration, reduction of the visual field, and difficulties in eating. In our cases, apart from the aesthetic point of view, rhinophyma interfered with the normal speech and nutrition of the patients.

Both our patients did not seek medical help for rhinophyma, but they delayed it for years. The COVID-19 pandemic imposed the wearing of masks and they were able to cover up their facial asymmetry and to postpone the treatment of rhinophyma. Among the main reasons for not seeking earlier medical help were the fear and the shame of the way they were looking, following the disease.

The treatment of rhinophyma can be very provocative and involves a combination of different options. As the oral medications are not usually effective in established rhinophyma, surgery is often necessary ${ }^{7}$. The extent of tissue growth and the severity of the condition can help to determine the preferred method of treatment?

There is no consensus regarding the management of rhinophyma and many surgeons follow the

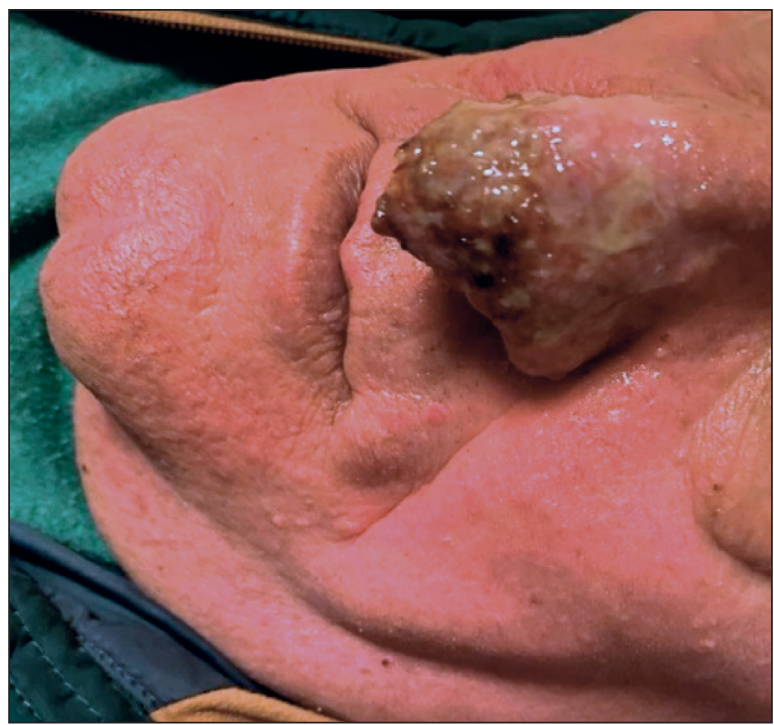

Fig. 6. Patient 2 on the $14^{\text {th }}$ day after surgery 
"to each his own technique" mindset ${ }^{8}$. The outcome depends on the selected treatment and the qualification of the surgeon. There have been published several case reports about different surgical methods in rhinophyma treatment. In some cases, when patients have other comorbidities like cardiac failure, impaired hemostasis, or allergies to anesthesia drugs, the possibilities to treat rhinophyma are some light treatments and laser $\left(\mathrm{CO}_{2} \text {, Argon, } \mathrm{Nd} \text { : } \mathrm{YAG}\right)^{8}$. Laser therapies are successful methods since eradicating telangiectasias leads to decreased blood supply to the hypertrophic tissue and subsequent tissue reduction, they can carefully cut and vaporize skin while obliterating sebaceous glands and expression of sebum ${ }^{1,9}$. Laser treatment and dermabrasion have the advantages of precise hemostasis and contouring of

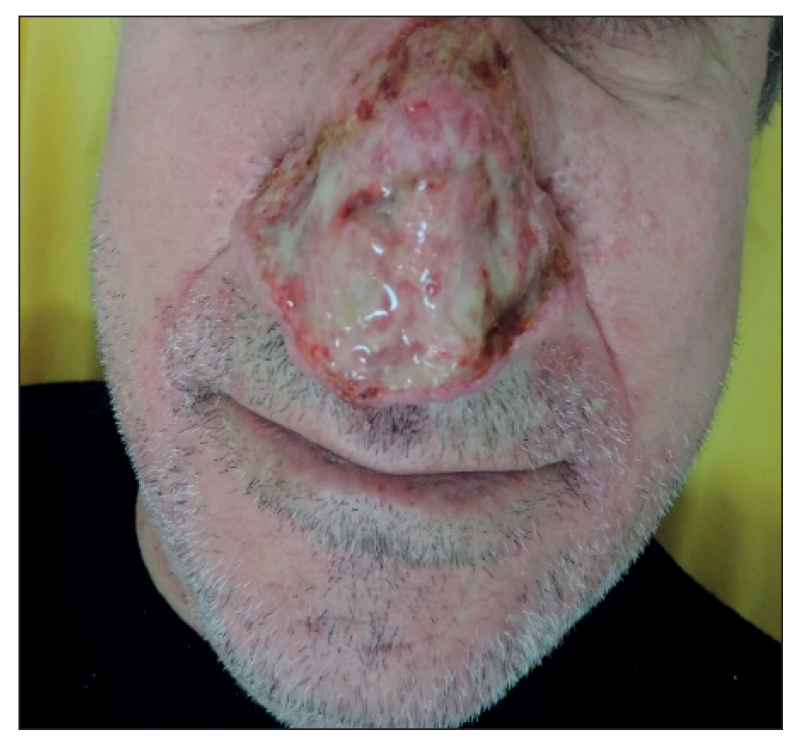

Fig. 7. Patient 1 on the $30^{\text {th }}$ day after surgery

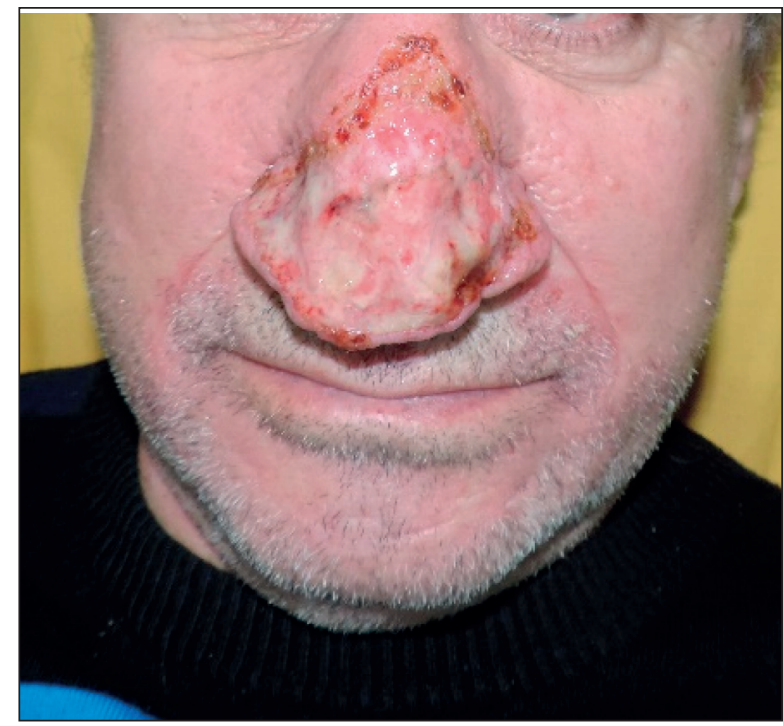

Fig. 9. Patient 1, three months after surgery an aesthetic nasal shape ${ }^{7,10,11}$. The main limitations of laser therapy are imprecise tissue removal, risk of scarring, dyspigmentation, and bleeding, which can obstruct visualization ${ }^{1,10}$.

Other useful methods for rhinophyma treatment reported in the scientific literature are hydro dissection (versajet system), mechanical dermabrasion, and surgical excision ${ }^{3,12,13}$. The advantages of methods like hydro-dissection and mechanical dermabrasion are that the operations do not take a long time. The disadvantages are that they cannot be performed so precisely, the cartilage is often injured, and the healing is slow.

While laser treatment, hydro dissection and dermabrasion are used in the initial stages of the disease, for small lesions, the classical surgical excision is the preferred method for severe cases of rhinophyma,

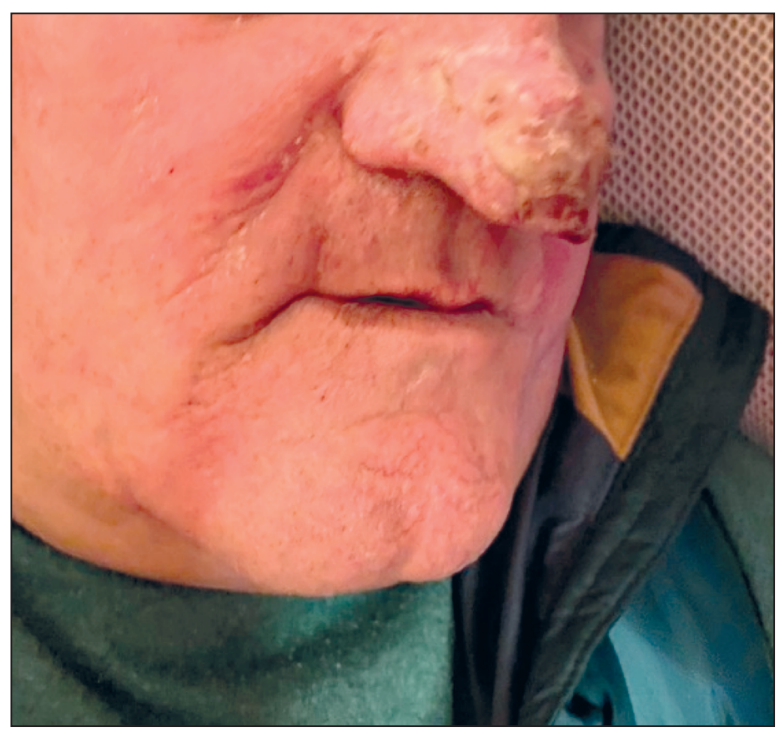

Fig. 8. Patient 2 on the $30^{\text {th }}$ day after surgery

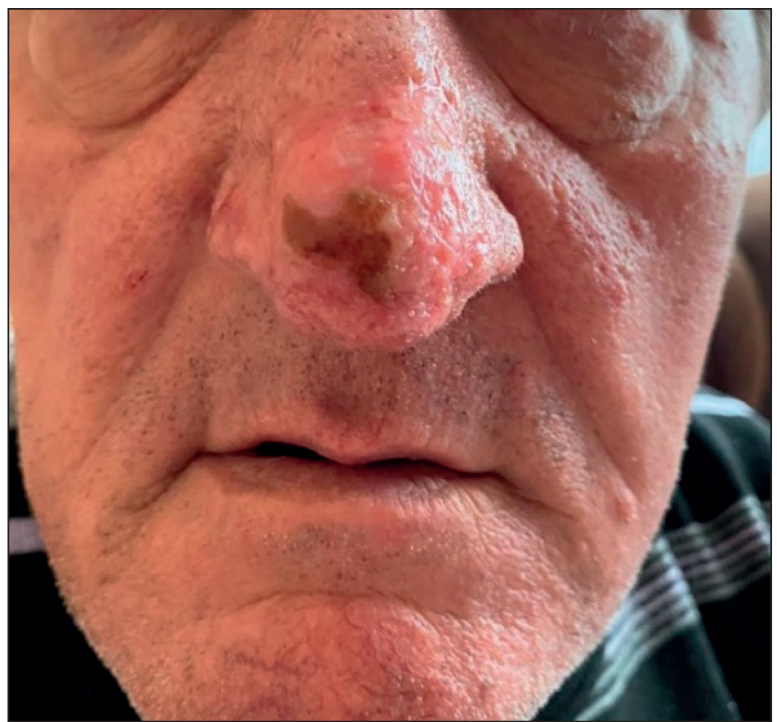

Fig. 10. Patient 2, three months after surgery 
when the lesion is large ${ }^{12}$. Larger and more advanced cases may require several surgical procedures, whereas minor cases can be treated simply with a sterile single-blade disposable razor ${ }^{14}$.

In our cases, we preferred the classical surgical excision using a scalpel, to shave off the abnormal tissue, to treat the large rhinophymas, remove the excess tissue, and restore the natural appearance of the nose. The main reason to choose this procedure was the opportunity of debulking the excess tissue layer by layer. With this technique, we could also maintain the viability of more sebaceous and sweat glands, which in turn favors the healing process and leads to contouring an aesthetic nasal shape. Our aim was to obtain a reduction of the abnormal tissue, by debulking and fine contouring, followed by hemostasis and a very careful postoperative assistance ${ }^{15}$. The advantages of the procedure are that it is easy to perform, leads to a significant result and there are no complications such as scarring or hyperpigmentation?

In most of the published case reports about this pathology, the specialists used laser-assisted surgery, microdebrider- assisted rhinophyma excision or combination of methods like surgical excision and/or electrocautery with dermabrasion etc ${ }^{8,16}$. By surgery, we managed in a single procedure to remove the excess phymatous skin, solve the respiratory problems, remove the eating discomfort and create an aesthetic contour of the nose, which proves the advantages of this method. A simple surgical excision can be considered a good treatment option for rhinophyma, as it results in an excellent cosmetic outcome and has short recovery time. Patients were completely healed, without any postoperative infections or other complications, without any signs of recurrence. Due to the good aesthetic result, the patients were reintegrated into society.

\section{Conclusions}

Rhinophyma is a painless benign tumour of the skin of the nose. The exact cause of rhinophyma is not known, but it is thought to be multifactorial, with a primary etiology of unregulated superficial vasodilatation $^{12}$. It is a slowly progressive enlargement with irregular thickening of the nasal skin and nodular deformation that will not resolve spontaneously ${ }^{6}$.

The functional reasons, such as obstruction of the nasal respiration and reduction of the visual field, as well as the plastic and cosmetic reasons are usual indications of the need of treatment. Many treatment options are available for rhinophyma, but there is no standard treatment protocoll? Usually, the treatment of rhinophyma consists of surgical removal of the hyperplastic alterations and it should always be performed by an experienced rhino surgeon.

\section{Author Contributions}

R.T. is responsible for the diagnostic procedures, performed the surgery, wrote the manuscript and did substantial contributions to its conception and design. G.Y. is responsible for the treatment decisions and participated in the analysis and interpretation of data, as well as drafting of the article. N.P. collected the data and participated in the conception, design and drafting of the article. All authors have read and agreed to the final published version of the manuscript.

\section{Compliance with Ethics Requirements:}

"The authors declare no conflict of interest regarding this article"

"The authors declare that all the procedures and experiments of this study respect the ethical standards in the Helsinki Declaration of 1975, as revised in 2008(5), as well as the national law. Informed consent was obtained from all the patients included in the study"

"No funding for this study"

\section{Acknowledgements:}

None

\section{References}

1. Dick MK, Patel BC. Rhinophyma. StatPearls [Internet]. 2020 Jan. Available from: https://www.ncbi.nlm.nih.gov/ books/NBK544373/

2. Laun J, Gopman J, Elston JB, Harrington MA. Rhinophyma. Eplasty [Internet]. 2015; 15:ic25. Available from: https:// pubmed.ncbi.nlm.nih.gov/25987948/

3. Ivanova S, Susoeva A, Mesentsev N, Clatici V. Rhinophyma treated by surgery - case presentation. RoJCED [Internet]. 2017; 1(4):34-36. Available from: https://www.researchgate. net/publication/317186060_RHINOPHYMA_TREATED_ BY_SURGERY__CASE_PRESENTATION

4. Little SC, Stucker FJ, Compton A, Park SS. Nuances in the management of rhinophyma. Facial Plast Surg [Internet]. 2012; 28(2):231-7. Available from: https://pubmed.ncbi.nlm. nih.gov/22562574/ DOI: 10.1055/s-0032-1309304

5. Fink C, Lackey J, Grande DJ. Rhinophyma: a treatment review. Dermatol Surg [Internet]. 2018 Feb; 44(2):275-282. Available from: https://pubmed.ncbi.nlm.nih. gov/29140869/ DOI: 10.1097/DSS.0000000000001406

6. Sadick H, Riedel F, Bran G. Rhinophyma in rosacea. What does surgery achieve? Hautarzt [Internet]. 2011; 62(11):834-41. Available from: https://pubmed.ncbi.nlm. nih.gov/22006169/ DOI: 10.1007/s00105-011-2146-5.

7. Hamzawi N, Baaj S. Large rhinophyma treated by surgical excision and electrocautery. Hindawi Case Reports in Surgery [Internet]. 2019. Available from: https://www.researchgate.net/publication/334704615_Large_Rhinophyma_ Treated_by_Surgical_Excision_and_Electrocautery DOI: 10.1155/2019/2395619

8. Chellappan B, Castro J. Management of severe rhinophyma with electrocautery dermabrasion - A case report. Int J Surg Case Rep [Internet]. 2020; 72: 511-514. Available from: 
https://www.ncbi.nlm.nih.gov/pmc/articles/PMC7317162/ DOI: $10.1016 /$ j.ijscr.2020.06.039

9. Ponomarev I, Topchiy S, Klyuchareva S, Pushkareva A. Rhinophyma treatment by copper vapor laser with the computerized scanner. J Lasers Med Sci [Internet]. 2019; 10(2):153-156. Available from: https://pubmed.ncbi.nlm. nih.gov/31360385/ DOI: 10.15171/jlms.2019.24.

10. Del Rosso J, Tanghetti E, Webster G, Gold L, Thiboutot D, Gallo R. Update on the management of Rosacea from the American Acne \& Rosacea Society (AARS). J Clin Aesthet Dermatol [Internet]. 2019; 12(6):17-24. Available from: https://pubmed.ncbi.nlm.nih.gov/31360284/

11. Merigo E, Cella L, Oppici A, Fornaini C. Laser-assisted surgery and bio scaffold for the treatment of rhinophyma. Indian J Dermatol Venereol Leprol [Internet]. 2018; 84(5):629-631. Available from: https://pubmed.ncbi.nlm. nih.gov/29327702/DOI: 10.4103/ijdvl.IJDVL_781_16.

12. Popa D, Osman G, Parvanescu H, Ciurea R, Ciurea M. The treatment of giant rhinophyma - case report. Curr Health Sci $J$ [Internet]. 2012;38(1):41-44. Available from: https://www. ncbi.nlm.nih.gov/pmc/articles/PMC3945259/
13. Javed M, Hague A, O'Leary B, Murison MS. CO2 laser treatment of rhinophyma. The PMFA Journal [Internet]. 2021;8(2). Available from: https://www.researchgate.net/ publication/346791315_CO2_laser_treatment_of_rhinophyma

14. Morandi E, Verstappen R, Metzler J, Kronberger P, Pierer G, Djedovic G. An old problem with a new solution: cost-effective, easy correction of rhinophyma using a disposable razor. Arch Plast Surg [Internet]. 2018; 45(5):490-492. Available from: https://pubmed.ncbi.nlm.nih.gov/30282423/ DOI: 10.5999/aps.2017.01452.

15. Bonavolontà P, Giovanni D, Goglia F, et al. A new surgical approach for the treatment of Rhinophyma. Ann Ital Chir [Internet]. 2020; 9:S2239253X20033150. Available from: https://pubmed.ncbi.nlm.nih.gov/33427205/

16. Abushaala A, Stavrakas M, Khalil H. Microdebrider-assisted rhinophyma excision. Case Rep Otolaryngol [Internet]. 2019; 2019:4915416. Available from: https://pubmed.ncbi.nlm. nih.gov/31885991/ DOI: 10.1155/2019/4915416. 